\title{
Dosis Optimum Pupuk Granular Lindi Sampah Kota Terhadap Kandungan Nitrogen pada Media Pembibitan Tanaman Lada
}

\author{
Ansyori $^{1}$, Toniyawan Herdiyansyah ${ }^{2}$, Yanto ${ }^{1}$ \\ ${ }^{1}$ Sekolah Tinggi Perkebunan Lampung, Bandar Lampung \\ 2Politeknik Negeri Lampung, Bandar Lampung \\ Submisi:8 Oktober 2021; Penerimaan: 27 Desember 2021
}

\begin{abstract}
ABSTRAK
Lindi sampah kota memiliki kandungan unsur hara makro dan mikro essensial bagi tanaman. Namun, kandungan senyawa pada lindi belum memenuhi standar sebagai pupuk organik cair, sehingga perlu upaya pemekatan agar lebih berdayaguna. Penelitian ini bertujuan untuk mengetahui pengaruh peningkatan dosis pupuk granular berbahan dasar lindi sampah kota terhadap kandungan nitrogen pada media pembibitan lada (Piper nigrum L.). Penelitian disusun menggunakan Rancangan Acak Kelompok Lengkap (RAKL). Perlakuan terdiri dari lima taraf dosis pupuk granular lindi sampah kota yaitu: tanpa pupuk $\left(P_{0}\right) ; 10 \mathrm{gram} /$ polibag $\left(P_{1}\right) ; 20$ gram/polibag $\left(P_{2}\right) ; 30 \mathrm{gram} /$ polibag $\left(P_{3}\right) ;$ dan $40 \mathrm{gram} /$ polibag $\left(P_{4}\right)$. Penelitian dibagi lima kelompok yang sekaligus menjadi ulangan, sehingga terdiri dari 25 satuan percobaan dan setiap satuan percobaan terdiri dari lima media pembibitan tanaman lada. Untuk mengetahui pengaruh pelakuan dilakukan analisis kesamaan ragam data dengan uji Bartlett dan keaditifan data dengan uji Tukey. Data dianalisis dengan analisis ragam dan dilanjutkan dengan uji Beda Nyata Terkecil, Perbandingan Ortogonal, dan Ortogonal Polinomial pada taraf pengujian 5\%. Hasil penelitian menunjukan bahwa pupuk granular berbahan dasar Lindi sampah kota mampu meningkatkan kandungan nitrogen dalam media pembibitan tanaman lada. Dosis pupuk granular lindi sampah kota $20 \mathrm{~g}$ /polibag merupakan dosis terbaik dengan kandungan N 0,35\%. Namun kandungan N media pembibitan lada tanpa pupuk tidak berbeda nyata dengan dosis 10, 30, dan $40 \mathrm{~g} /$ polibag. Peningkatan dosis pupuk granular lindi sampah kota mampu meningkatkan kandungan nitrogen mengikuti pola kuadratik, dengan persamaan $y=-0,00009 x^{2}+0,0035 x+0,2828 ; R^{2}=0,3106$.
\end{abstract}

Kata kunci: Nitrogen; Pupuk Granular; Lindi Sampah Kota; Tanaman Lada

\section{PENDAHULUAN}

Unsur Nitrogen $(\mathrm{N})$ dibutuhkan oleh tanaman dalam jumlah yang besar, umumnya menjadi faktor pembatas pada tanah-tanah yang tidak dipupuk. Unsur N dapat berupa asam amino, amida, dan amin yang berfungsi sebagai kerangka (building blocks) dan senyawa antara (intermediary compounds) di dalam tanaman. Bahan tanaman kering mengandung $2-4 \% \mathrm{~N}$. Bentuk ion yang diserap oleh tanaman umumnya dalam bentuk $\mathrm{NO}_{3}$ - dan $\mathrm{NH}_{4}{ }^{+}$(Heryanita, 2017; Triadiawarman, 2017; dan Subiksa, 2018). Begitu besarnya peranan $N$ bagi tanaman, maka penyediaannya perlu diperhatikan.

Kebutuhan tanaman akan unsur hara dapat diperoleh dari media tanam, namun biasanya unsur hara terdapat dalam jumlah yang sedikit dan tidak lengkap, sehingga tidak dapat memenuhi kebutuhan tanaman. Oleh karena itu, diperlukan tambahan unsur hara berupa pupuk. Pemberian pupuk secara berkala dengan dosis yang tepat sangat menunjang pertumbuhan tanaman. Sebaliknya, pemberian pupuk yang berlebihan dan tidak tepat dosis akan 
menyebabkan pertumbuhan tanaman terganggu, bahkan dapat menyebabkan kematian (Purba, R., dan Rosalyne, I. 2019).

Menurut Mawaddah, Z. (2021), bahan organik umumnya mengandung unsur hara makro yang rendah, tetapi memiliki kandungan unsur hara mikro yang cukup untuk pertumbuhan tanaman. Bahan organik mempunyai fungsi yang penting yaitu menggemburkan lapisan tanah permukaan (top soil), meningkatkan populasi jasad renik, mempertinggi daya serap dan daya simpan air, yang keseluruhannya dapat meningkatkan kesuburan tanah. Bahan organik dapat bersumber dari residu tumbuhan maupun hewan, yang banyak terkandung dalam air lindi sampah kota.

Air lindi terbentuk di setiap lokasi pembuangan sampah. Pembentukan lindi merupakan dari infiltrasi dan perkolasi (perembesan air dalam tanah) dari air hujan, air tanah, air limpasan atau air banjir yang menuju lokasi pembuangan sampah (Sarwono, Azis, dan Widarti, 2017). Sumber sampah yang terbanyak dari pemukiman dan pasar tradisional. Sampah pasar khusus seperti sayur mayur, pasar buah atau pasar ikan, jenisnya relatif seragam, sebagian besar (96\%) berupa sampah organik sehingga lebih mudah ditangani. Sampah yang berasal dari pemukiman umumnya sangat beragam, tetapi secara umum minimal $75 \%$ terdiri dari sampah organik dan sisanya sampah anorganik (Suardana dan Rahayu, 2021).

Air lindi memiliki kandungan yang merupakan unsur hara makro dan mikro essensial, antara lain unsur logam $\mathrm{Cu}$, $\mathrm{Fe}, \mathrm{Zn}$, dan Mn. Namun, Arya dan Gilar (2008) mengemukakan bahwa kandungan senyawa yang terdapat pada lindi belum memenuhi standar seperti yang ditentukan Departemen Pertanian $\mathrm{RI}$ sehingga pupuk organik cair dari lindi sampah kota belum dapat langsung dipasarkan. Oleh karena itu, perlu upaya pemekatan agar lebih berdayaguna, salah satunya dengan pemanfaatan air lindi sampah kota sebagai bahan dasar pembuatan pupuk granular.

Tanaman lada yang termasuk famili Piperaceae merupakan tanaman yang banyak dibudidayakan di Indonesia (Eka Permana, G. 2019) dan banyak memerlukan unsur $\mathrm{N}$. Oleh karena itu perlu dilakukan penelitian yang bertujuan untuk mengetahui pengaruh peningkatan dosis pupuk granular lindi sampah kota terhadap kandungan unsur $\mathrm{N}$ pada media pembibitan tanaman lada (Piper nigrum L.).

\section{METODE PENELITIAN}

\section{Tempat dan Bahan}

Penelitian dilaksanakan pada lahan pembibitan Politeknik Negeri Lampung dan analisis $\mathrm{N}$ dilaksanakan di Laboratorium Tanah Politeknik Negeri Lampung. Bahan yang digunakan antara lain: top soil, pasir, pupuk granular lindi sampah kota (pasar kota Bandar Lampung), bibit tanaman lada, bahan kimia untuk analisis $\mathrm{N}$ (CuSO4, $\mathrm{NaSO}_{4}$, $\mathrm{H}_{2} \mathrm{SO}_{4}$, aquades, $\mathrm{NaOH} 40 \%$, Nessler $\mathrm{A}$ dan B), polibag ukuran $10 \times 20 \mathrm{~cm}$, dan kertas koran. Alat yang digunakan antara lain: Spektrofotometer $\lambda=460 \mathrm{~nm}$, alat pengolah tanah, handsprayer, alat tulis, meteran, paranet $80 \%$, kamera, dan kertas label.

\section{Rancangan Percobaan}

Penelitian ini dilaksanakan dengan metode eksperimen yang dirancang menggunakan Rancangan Acak Kelompok Lengkap (RAKL) dengan lima ulangan. Perlakuan terdiri dari lima taraf dosis pupuk granular lindi sampah kota yaitu: tanpa pemberian pupuk $\left(\mathrm{P}_{0}\right) ; 10$ gram/polibag $\left(P_{1}\right) ; 20$ gram/polibag $\left(P_{2}\right)$; 30 gram/polibag $\left(\mathrm{P}_{3}\right) ;$ dan 40 gram/polibag $\left(P_{4}\right)$. Satuan percobaan 
berjumlah 25, dan setiap satuan percobaan terdiri dari lima media pembibitan tanaman lada.

\section{Pelaksanaan Penelitian}

Kegiatan yang dilakukan selama penelitian adalah: penyiapan lahan penelitian, penyiapan media tanam, penanaman bibit lada, aplikasi pupuk, pemeliharaan, pengambilan sampel dan analisis tanah, serta analisis data.

Penyiapan lahan dilakukan dengan membersihkan dan meratakan lahan, serta pembuatan naungan dengan ketinggian 1,75 $\mathrm{m}$ dengan atap paranet. Penyiapan media tanam diawali dengan membersihkan media dari batu-batuan, sisa-sisa tanaman, dan benda-benda yang tidak dikehendaki dengan menggunakan saringan, agar media homogen. Selanjutnya membuat media tanam yang berasal dari campuran top soil dan pasir dengan perbandingan 1:1, lalu memasukkannya ke polibag. Polibag yang telah diisi media tanam disusun pada bedeng pembibitan sesuai tata letak percobaan, mengikuti pola Rancangan Acak Kelompok Lengkap (Mattjik, A. A., dan Sumertajaya, I. M. 2013).

Penanaman bibit lada hasil penyemaian dilakukan dengan memindahkannya ke dalam polibag. Agar satuan percobaan homogen, selanjutnya dilakukan pengelompokan polibag berdasarkan tinggi dan jumlah helai daun bibit tanaman lada. Aplikasi pupuk dilakukan hanya sekali setelah bibit lada berumur 2 minggu setelah tanam sesuai dosis perlakuan. Sebelum diaplikasikan pupuk diambil sampelnya untuk dianalisis kandungan unsur haranya di laboratorium, mengikuti prosedur SNI (2010). Pupuk diaplikasikan dengan menabur pada larikan yang melingkar dengan jarak 5 $\mathrm{cm}$ dari pangkal batang dan ditutup dengan media. Bibit lada dipelihara secara rutin dengan melakukan penyiraman dan pengendalian hama, penyakit, serta gulma tanaman (Utoyo, Gusta, Sukmawan, dan Same., 2018).

\section{Sampel dan Analisis Tanah}

Pengambilan sampel tanah dari setiap satuan percobaan dilakukan pada saat bibit lada berumur 3 bulan setelah tanam, dengan harapan unsur hara yang berasal dari pupuk granuler berbahan dari lindi telah tersedia bagi tanaman. Pengambilan sampel tanah menggunakan sendok dari bagian tengah media. Masing-masing sampel seberat 50 gram dikompositkan, yang selanjutnya dilakukan analisis kandungan $\mathrm{N}$-total di laboratorium.

Analisis kandungan $\mathrm{N} \quad \mathrm{di}$ laboratorium dilakukan dengan dua tahap umum yaitu preparasi dan pengukuran. Preparasi contoh dilakukan mengikuti prosedur SNI (2010), sedangkan pengukuran kandungan $\mathrm{N}$ dilakukan dengan metode Spektrofotometer, mengikuti prosedur pengujian menurut Balai Penelitian Tanah (2005): (1) menimbang sampel tanah seberat 1 gram dan menempatkan pada labu Kjeldahl; (2) menambahkan selen $\left(\mathrm{CuSO}_{4}+\mathrm{NaSO}_{4}\right)$ seberat 1 gram pada sampel tanah; (3) menambahkan $\mathrm{H}_{2} \mathrm{SO}_{4}$ pekat sebanyak $5 \mathrm{ml}$ ke dalam labu Kjeldahl yang telah berisi sampel tanah dan selen; (4) mendestruksi larutan dengan suhu $350^{\circ} \mathrm{C}$ selama 3 jam, lalu dilakukan pendinginan; (5) menambahkan aquades sebanyak 100 ml, kemudian menambahkan $\mathrm{NaOH} 40 \%$ sebanyak $17 \mathrm{ml}$; (6) menambahkan air akuades sampai volume $250 \mathrm{ml}$, kemudian dilakukan penyaringan; (7) hasil penyaringan diambil $10 \mathrm{ml}$ dan menambahkan Nessler A dan Nessler B; (8) mengukur kandungan $\mathrm{N}$ dengan spektrofotometer.

\section{Analisis Data}

Untuk mengetahui pengaruh pelakuan dilakukan analisis kesamaan 
ragam data dengan uji Bartlett dan keaditifan data dengan uji Tukey. Data dianalisis dengan analisis ragam (ANOVA) dan dilanjutkan dengan uji Beda Nyata Terkecil (BNT), Perbandingan Ortogonal, dan Ortogonal Polinomial pada taraf pengujian $5 \%$.

\section{HASIL DAN PEMBAHASAN}

Hasil penelitian menunjukkan bahwa dosis pupuk granular berbahan dasar lindi sampah kota berpengaruh sangat nyata terhadap kandungan $\mathrm{N}$ media pembibitan tanaman lada. Berdasarkan hasil uji Perbandingan
Ortogonal (Tabel 1) menunjukkan bahwa pemberian pupuk granular lindi sampah kota mampu meningkatkan kandungan $\mathrm{N}$ rata-rata $6,83 \%$ dibandingkan tanpa dipupuk.

Berdasarkan hasil uji BNT pada taraf nyata 5\% (Tabel 2) menunjukkan bahwa dosis pupuk granular lindi sampah kota 20 g/polibag $\left(P_{2}\right)$ merupakan dosis terbaik dengan kandungan $\mathrm{N} 0,35 \%$. Namun kandungan $\mathrm{N}$ media pembibitan lada yang tidak diberi pupuk $\left(\mathrm{P}_{0}\right)$ tidak berbeda nyata dengan dosis 10,30 , dan $40 \mathrm{~g} /$ polibag $\left(\mathrm{P}_{1}, \mathrm{P}_{3}\right.$, dan $\left.\mathrm{P}_{4}\right)$.

Tabel 1. Hasil Uji Perbandingan Ortogonal Data Pengaruh Dosis Pupuk Granular Lindi Sampah Kota terhadap Kandungan N

\begin{tabular}{cccccc}
\hline \multirow{2}{*}{ Perbandingan } & \multicolumn{2}{c}{ Rata-rata } & \multirow{2}{*}{ Selisih } & Peningkatan & Perbedaan \\
\cline { 2 - 5 } & $\mathrm{P}_{0}$ & $\mathrm{P}_{1}, \mathrm{P}_{2}, \mathrm{P}_{3}, \mathrm{P}_{4}$ & & & \\
\hline $\mathrm{P}_{0}$ Vs $\mathrm{P}_{1}, \mathrm{P}_{2}, \mathrm{P}_{3}, \mathrm{P}_{4}$ & $0,28 \%$ & $0,30 \%$ & $0,02 \%$ & $6,83 \%$ & ${ }^{*}$ \\
\hline
\end{tabular}

Keterangan: $P_{0}=$ tanpa pupuk; $P_{1}=10$ g/polibag; $P_{2}=20$ g/polibag; $P_{3}=30$ g/polibag; dan $P_{4}=40$ $\mathrm{g} /$ polibag ${ }^{* *}=$ berpengaruh nyata pada taraf $1 \%$

Tabel 2. Hasil Uji Beda Nyata Terkecil Pengaruh Dosis Pupuk Granular Lindi Sampah Kota terhadap Kandungan N

\begin{tabular}{ll}
\hline Dosis Pupuk Granular & $\mathrm{N}(\%)$ \\
\hline $\mathrm{P}_{0}=$ tanpa pupuk & $0,28^{\mathrm{b}}$ \\
$\mathrm{P}_{1}=10 \mathrm{~g} /$ polibag & $0,28^{\mathrm{b}}$ \\
$\mathrm{P}_{2}=20 \mathrm{~g} /$ polibag & $0,35 \mathrm{a}$ \\
$\mathrm{P}_{3}=30 \mathrm{~g} /$ polibag & $0,29^{\mathrm{b}}$ \\
$\mathrm{P}_{4}=40 \mathrm{~g} /$ polibag & $0,29^{\mathrm{b}}$ \\
\hline BNT 0,05=0,01 & 0,30 \\
\hline Keterangan: huruf dibelakang angka \\
yang berbeda menunjukkan adanya \\
perbedaan nyata menurut uji BNT \\
pada taraf $5 \%$
\end{tabular}

Hasil uji Ortogonal Polinomial (Tabel 3) menunjukkan peningkatan dosis pupuk granular lindi sampah kota mampu meningkatkan kandungan $\mathrm{N}$ tanah mengikuti pola kuadratik. Mulamula penambahan dosis pupuk granular lindi sampah kota meningkatkan kandungan $\mathrm{N}$ tanah sampai dengan dosis optimum, selanjutnya penambahan dosis akan menurunkan kandungan $\mathrm{N}$.
Berdasarkan persamaan kuadrat y $=-0,00009 x^{2}+0,0035 x+0,2828 ; R^{2}=$ 0,3106 (Gambar 2), maka diperoleh dosis pupuk granular lindi sampah kota optimum sebesar 19,4 gram/polibag dengan kandungan N 0,30\%. Respon kandungan $\mathrm{N}$ pada media pembibitan tanaman lada terhadap dosis pupuk granular lindi sampah kota sebesar $31,06 \%$.

Hasil penelitian menunjukkan pemberian pupuk granular berbahan dasar lindi sampah kota mampu meningkatkan kandungan $\mathrm{N}$ media pembibitan tanaman lada. Hal tersebut karena pupuk granular lindi sampah kota mengandung unsur hara $\mathrm{N}$ sebanyak $0,255 \%$ sebagaimana hasil analisis laboratorium kandungan pupuk pada penelitian ini (Tabel 4). Peningkatan kandungan $\mathrm{N}$ tersebut sejalan dengan hasil penelitian Riansyah dan Wesen (2012) yang menunjukkan karakteristik awal air lindi sampah sebelum dijadikan 
pupuk dengan kandungan C-organik 0,42\%; N-total 0,02\%; P 0,014\%; dan K $0,20 \%$. N-total meningkat selama proses pembuatannya menjadi pupuk. Hasil tersebut dikarenakan adanya proses dekomposisi protein melalui reaksireaksi seperti amonifikasi dan nitrifikasi.
Demikian juga halnya dengan hasi penelitian Hanafi dan Yulipriyanto (2014), yang menyatakan bahwa penambahan air lindi dalam pengomposan sampah daun dapat meningkat kandungan $\mathrm{N}$-total.

Tabel 3. Uji Ortogonal Polinomial Data Pengaruh Dosis Pupuk Granular Lindi Sampah Kota terhadap Kandungan $\mathrm{N}$

\begin{tabular}{|c|c|c|c|c|c|c|c|c|c|c|}
\hline \multirow{2}{*}{ Pengaruh } & \multicolumn{5}{|c|}{ Total Perlakuan } & \multirow{2}{*}{$\begin{array}{l}\text { Jumlah } \\
\text { Kuadrat }\end{array}$} & \multirow{2}{*}{\multicolumn{2}{|c|}{ F-Hitung }} & \multirow{2}{*}{\multicolumn{2}{|c|}{ F-Tabel }} \\
\hline & $\mathrm{P}_{0}$ & $P_{1}$ & $\mathrm{P}_{2}$ & $\mathrm{P}_{3}$ & $\mathrm{P}_{4}$ & & & & & \\
\hline Linier & -2 & -1 & 0 & 1 & 2 & 0,000002 & 0,09 & ns & 4,49 & 8,53 \\
\hline Kuadratik & 2 & -1 & -2 & -1 & 2 & 0,005456 & 236,86 & & & \\
\hline Kubik & -1 & 2 & 0 & -2 & 1 & 0,000024 & 1,06 & ns & & \\
\hline Kuartik & 1 & -4 & 6 & -4 & 1 & 0,012089 & 524,82 & & & \\
\hline
\end{tabular}

Keterangan: $P_{0}=$ tanpa pupuk; $P_{1}=10 \mathrm{~g} /$ polibag; $P_{2}=20 \mathrm{~g} /$ polibag; $P_{3}=30 \mathrm{~g} /$ polibag; dan $\mathrm{P}_{4}=40 \mathrm{~g} /$ polibag; $\mathrm{ns}=$ tidak berpengaruh nyata pada taraf $5 \% \%^{* *}=$ berpengaruh nyata pada taraf $1 \%$.

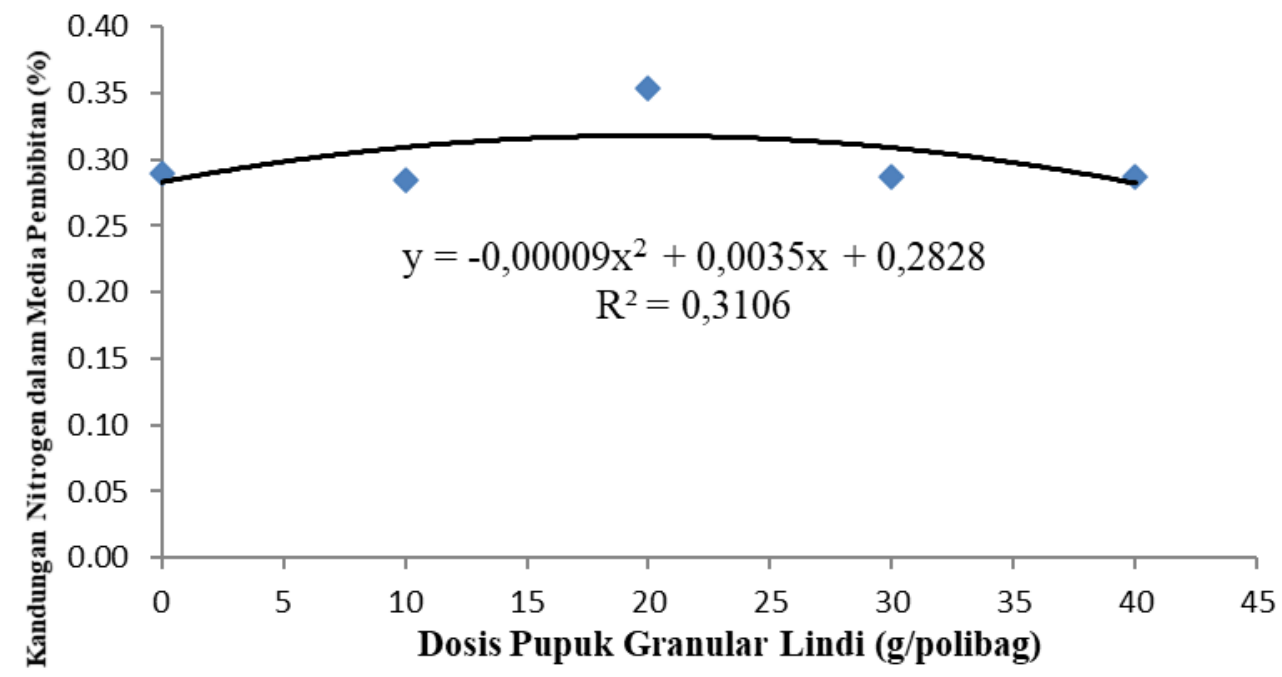

Gambar 2. Pengaruh Dosis Pupuk Granular Lindi Sampah Kota terhadap Kandungan N pada Media Pembibitan Tanaman Lada

Tabel 4. Hasil Analisis Laboratorium Kandungan Pupuk Granular Berbahan Dasar Lindi Sampah Kota

\begin{tabular}{cc}
\hline Unsur Hara & Jumlah (\%) \\
\hline N-Total & 0,255 \\
P Tersedia & 0,453 \\
K Total & 0,300 \\
C-Organik & 1,333 \\
\hline
\end{tabular}

Peningkatan dosis pupuk granular berbahan dasar lindi sampah kota sampai dengan 19,4 gram/polibag akan semakin meningkatkan kandungan $\mathrm{N}$ sampai optimum, selanjutnya penambahan dosis akan menurunkan kandungan N. Peningkatan kandungan N tersebut tergolong rendah, oleh karena itu perlu dilakukan penambahan bakteri 
sebagai starter pada lindi, sebagaimana hasil penelitian Dimiati dan Hadi (2017) yang menyatakan penambahan bakteri starter dan pengenceran lindi mampu meningkatkan kandungan amonium dan nitrat.

Penurunan kandungan $\mathrm{N}$ pada dosis yang lebih tinggi, diduga karena lindi mengandung unsur-unsur logam seperti $\mathrm{Sn}, \mathrm{Cd}, \mathrm{Cu}$, dan Fe (Kusumawati, T. 2012), yang akan menghambat kerja bakteri penambat $\mathrm{N}$ pada media tanam. Penurunan kandungan $\mathrm{N}$ dalam media tanam bibit lada juga dikarenakan diserap oleh bibit tanaman lada (Hazra, Gusmaini, dan Wijayanti, 2019) atau hilang tercuci. $\mathrm{N}$ termasuk unsur yang mobil di dalam tanah, sehingga mudah hilang melalui proses pencucian (leaching) dalam bentuk nitrat (Ginting, Rahutomo, dan Sutarta, 2021).

\section{KESIMPULAN DAN SARAN}

Hasil penelitian uji dosis pupuk granular berbahan dasar lindi sampah kota terhadap kandungan $\mathrm{N}$ dalam media pembibitan lada dapat disimpulkan:

a) Pupuk granular berbahan dasar lindi sampah kota mampu meningkatkan kandungan $\mathrm{N}$ dalam media pembibitan tanaman lada.

b) Dosis pupuk granular lindi sampah kota $20 \mathrm{~g} /$ polibag merupakan dosis terbaik dengan kandungan $\mathrm{N}$ $0,35 \%$. Namun kandungan $\mathrm{N}$ media pembibitan lada tanpa pupuk $\left(\mathrm{P}_{0}\right)$ tidak berbeda nyata dengan dosis 10, 30, dan $40 \mathrm{~g} /$ polibag.

c) Peningkatan dosis pupuk granular berbahan dasar lindi sampah kota mampu meningkatkan kandungan $\mathrm{N}$ mengikuti pola kuadratik, dengan persamaan $y=-0,00009 x^{2}+$
$0,0035 x+0,2828 ; R^{2}=0,310$. Dosis optimum pupuk granular berbahan dasar lindi sampah kota tercapai pada 19,4 gram/polibag dengan kandungan $\mathrm{N}$ total $0,30 \%$.

Perlu penelitian lebih lanjut tentang pemanfaatan air lindi sampah kota sebagai bahan dasar pembuatan pupuk granular, dengan penambahan bahan starter pada berbagai parameter kandungan unsur hara dan pertumbuhan tanaman, serta dengan pembanding pupuk $\mathrm{N}$ standar.

\section{DAFTAR PUSTAKA}

Arya, K. dan G. M. Gilar. 2008. Pupuk cair organik tanah surga. http://tanahsurga.

blogspot.com/2008/09/pupuk-cair-organik-tanah-surga.html Diakses pada tanggal 12 Juni 2020.

Balai Penelitian Tanah. 2005. Petunjuk Teknis Analisis Kimia Tanah, Tanaman, Air, dan Pupuk. Bogor.

Dimiati, D. D. dan Hadi, W. 2017. Uji Pemanfaatan Pupuk Organik Cair Lindi Dengan Penambahan Bakteri Starter Terhadap Pertumbuhan Tanaman Hortikultura (Solanum Melongena dan Capsicum Frutescens).

http://ejurnal.its.ac.id/ index.php/teknik/article/view/2519 $9 / 0$

Eka Permana, G., 2019. Analisis Komponen Minyak Atsiri Lada Putih (Piper nigrum L.) Menggunakan KG-SM.

Ginting, E. N., Rahutomo, S., dan Sutarta, E. S. 2021. Efisiensi Relatif Pemupukan Metode Benam (Pocket) terhadap Metode Tebar (Broadcast) Di Perkebunan Kelapa Sawit. Warta Pusat Penelitian Kelapa Sawit, 26(2), 8192.

Hanafi, Y., dan Yulipriyanto, B. O. 2014. Pengaruh Penambahan Air Lindi terhadap Laju Dekomposisi Sampah Daun yang dikomposkan 
dalam

Vessel. J.

Bioedukatika, 2(2), 28.

Hazra, F., Gusmaini, G., dan Wijayanti, D. 2019. Aplikasi Bakteri Endofit dan Mikoriza Terhadap Kandungan Unsur N, P dan K pada Pembibitan Tanaman Lada. Jurnal IImu Tanah dan Lingkungan, 21(1), 42-50.

Heryanita, R. 2017. Optimasi pembentukan ammonium pada slow release fertilizer (Doctoral dissertation, Politekenik Negeri Sriwijaya).

Kusumawati, T. 2012. Kajian Degradasi Air Tanah Dangkal Akibat Air Lindi (Leachate) di Lingkungan Tempat Pembuangan Akhir Putri Cempo Surakarta (Doctoral dissertation, UNS (Sebelas Maret University).

Mattjik, A. A., dan Sumertajaya, I. M. 2013. Perancangan percobaan dengan aplikasi SAS dan Minitab. PT Penerbit IPB Press.

Mawaddah, Z. 2021. Pengaruh campuran konsentrasi pupuk organik cair bonggol pisang (Musa paradisiaca) dengan unsur hara makro nutrisi hidroponik terhadap pertumbuhan tanaman pakcoy (Brassica rapa L.) sistem NFT (Doctoral dissertation, UIN Sunan Gunung Djati Bandung).

Purba, R., dan Rosalyne, I. 2019. Pengaruh Perlakuan Dosis Pupuk Fosfat dan Konsentrasi Air Kolam Ikan Lele terhadap Pertumbuhan dan Produksi Tanaman Kacang Merah (Vigna angularis). Rhizobia: Jurnal Agroteknologi, 1(2), 34-46.

Riansyah, E., dan Wesen, P. 2012. Pemanfaatan Lindi Sampah sebagai Pupuk Cair. J. IIm. Tek. Lingkung, 4(1).

Sarwono, E., Azis, W. A., dan Widarti, B. N. 2017. Pengaruh Variasi Waktu Tinggal Terhadap Kadar BOD, COD, dan TSS pada Pengolahan Lindi TPA Bukit Pinang Samarinda Menggunakan Sistem Aerasi Bertingkat Sedimentasi. Journal dan Environmental Technology, 1(2).
SNI. Standar Nasional Indonesia. 2010. Pupuk NPK padat. 2803. Jakarta. (ID): SNI

Suardana, A. A. K., dan Rahayu, N. P. N. A. 2021. Pengenalan: Pengolahan Sampah Organik Berbasis "EcoEnzyme" Di Desa Batannyuh, Marga, Tabanan. Jurnal Sewaka Bhakti, 7(2), 81-87.

Subiksa, I. G. M. 2018. Perbandingan Pengaruh Beberapa Jenis Pupuk Mengandung Fosfat terhadap Kehilangan Hara Melalui Pelindian pada Tanah Gambut. Jurnal Lahan Suboptimal: Journal of Suboptimal Lands, 7(1), 1-13.

Triadiawarman, D. 2017. Analisis Kandungan C-Organik dan Nitrogen di Areal Tanaman Lai (Durio kutejensis) di Desa Peridan Kecamatan Sangkulirang Kabupaten Kutai Timur. Jurnal Pertanian Terpadu, 5(1), 98-104.

Utoyo, B., Gusta, A. R., Sukmawan, Y., dan Same, M. 2018. Pengembangan Unit Penangkar Bibit Lada Berkualitas Di Politeknik Negeri Lampung. J-Dinamika: Jurnal Pengabdian Masyarakat, 3(2).

Widyasari, N., Dewi Moelyaningrum, A., dan Sri Pujiati, R. 2013. Analisis potensi pencemaran timbal $(\mathrm{Pb})$ pada tanah, air lindi dan air tanah (sumur monitoring) di TPA Pakusari Kabupaten Jember. http://repository.unej.ac.id/handle/ 123456789/59247 